DOI https://doi.org/10.51647/kelm.2020.6.1.11

DZIALALNOŚĆ INNOWACYJNA W HARVARD MEDICAL SCHOOL (LATA 1870-1900)

\author{
Alla Kulichenko \\ kandydat nauk pedagogicznych, docent, \\ docent Katedry Języków Obcych \\ Zaporoskiego Państwowego Uniwersytetu Medycznego (Zaporoże, Ukraina), \\ doktorant Katedry Pedagogiki \\ Sumskiego Państwowego Uniwersytetu Pedagogicznego imienia A.S. Makarenki \\ (Sumy, Ukraina) \\ ORCID ID:0000-0003-1469-3816 \\ e-mail: alla.kulichenko@gmail.com
}

\begin{abstract}
Adnotacja. W latach 1870-1900 pomimo napiętej sytuacji społecznej, gospodarczej i politycznej w kraju Harvard Medical School była dużą instytucją edukacji medycznej, w której kadra profesorsko-dydaktyczna aktywnie prowadziła nie tylko działalność edukacyjną, ale także organizacyjną i naukową. Analiza, systematyzacja, uogólnienia źródeł naukowych i pedagogicznych oraz metoda historyczno-pedagogicznej rekonstrukcji wydarzeń i faktów pozwoliły na podkreślenie innowacyjnej działalności Harvard Medical School w latach 1870-1900. Należy zauważyć, iż powołanie Ch. Elliotta prezydentem Uniwersytetu Harvarda na początku lat 70. Harvard Medical School zwrócił na siebie znaczną uwagę, ponieważ miał pozytywne perspektywy rozwoju. Zmiany rozpoczęły się w procesie edukacyjnym zarówno dla studentów, jak i nauczycieli. Działalność innowacyjna naukowa i organizacyjna nadal się rozwijała. Ponadto stwierdzamy, że działalność innowacyjna była indywidualna i zespołowa. Nauczyciele eksperymentowali z programem nauczania, zakładali nowe wydziały, wprowadzali ciekawe i skuteczne metody nauczania i kursy elektryczne w czwartym roku studiów, uczestniczyli w opracowywaniu nowych narzędzi i aparatów, wykazywali udane operacje, odkrywali nowe choroby, proponowali rewolucyjne metody leczenia i tym podobne. Uczniowie stawali się bardziej odpowiedzialni i oddani przyszłemu zawodowi, zdobywając niezbędną wiedzę, zdolności i umiejętności zgodnie z ówczesnymi wyzwaniami społeczeństwa. Istotne dla przyszłych poszukiwań uważamy pokrycie ram regulacyjnych i prawnych innowacyjnych działań uczelni medycznych uniwersytetów amerykańskich w przekroju historycznym.

Słowa kluczowe: Amerykańska edukacja medyczna, Harvard Medical School, Massachusetts Medical College, innowacje, badania, odkrycia, Ch. Elliott, modernizacja.
\end{abstract}

\title{
INNOVATIVE ACTIVITY AT HARVARD MEDICAL SCHOOL (THE 1870-1900s)
}

\author{
Alla Kulichenko \\ Candidate of Pedagogical Sciences, Associate Professor, \\ Associate Professor at the Department of Foreign Languages \\ Zaporizhzhia State Medical University (Zaporizhzhia, Ukraine), \\ Postdoctoral Researcher at the Department of Pedagogy \\ Sumy State Pedagogical University named after A. S. Makarenko (Sumy, Ukraine) \\ ORCID ID: 0000-0003-1469-3816 \\ e-mail: alla.kulichenko@gmail.com
}

\begin{abstract}
In the 1870-1900s, despite the tense social, economic, and political situation in the country, Harvard Medical School was an incomparable institution of medical education, where faculty actively pursued not only educational but also organizational and scientific innovations. Analysis, systematization, generalization of scientific and pedagogical sources, and the method of historical and pedagogical reconstruction of events and facts enabled us to highlight the innovative activities of Harvard Medical School in the 1870-1900s. It should be noted that when Charles Eliot became the President of Harvard University in the early 1870s Harvard Medical School attracted considerable attention because it had positive prospects for development. Changes began in the educational process both for students and academic staff. Scientific and organizational innovation activities continued to develop. Besides, note that innovation was individual and collective. Professors experimented with the curriculum, established new departments, introduced interesting and effective teaching methods and elective courses within the fourth year of study, participated in the development of new tools and devices, demonstrated successful operations, discovered new diseases, proposed revolutionary treatments, etc. Students became more responsible and devoted to their future profession, gaining the necessary knowledge, skills, and abilities following the challenges of society at that time. As for future research, we consider covering the regulatory framework for the innovative activities of medical colleges in U.S. universities within historical terms.

Key words: American medical education, Harvard medical school, Massachusetts medical college, innovation, research, discovery, Ch. Eliot, modernization.
\end{abstract}




\title{
ІННОВАЦІЙНА ДІЯЛЬНІСТЬ У ГАРВАРДСЬКІЙ МЕДИЧНІЙ ШКОЛІ (1870-1900-ті рр.)
}

\author{
Алла Куліченко \\ кандидат педагогічних наук, доцент, \\ дочент кафедри іноземних мов \\ Запорізького державного медичного університету (Запоріжжя, Украӥна), \\ докторант кафедри педагогіки \\ Сумського державного педагогічного університету імені А. С. Макаренка (Суми, Україна) \\ ORCID ID:0000-0003-1469-3816 \\ e-mail:alla.kulichenko@gmail.com
}

\begin{abstract}
Анотація. У 1870-1900-ті pр., попри напружену соціальну, економічну та політичну ситуацію у країні, Гарвардська медична школа була непересічним закладом медичної освіти, де професорсько-викладацький склад активно провадив не тільки освітню, а й організаційну та наукову інноваційну діяльність. Аналіз, систематизація, узагальнення науково-педагогічних джерел і метод історико-педагогічної реконструкції подій і фактів дозволили висвітлити інноваційну діяльність Гарвардської медичної школи у 1870-1900-х рр. Варто зазначити, що після призначення Ч. Еліота президентом Гарвардського університету на початку 1870-х рр. Гарвардська медична школа привернула до себе значну увагу, оскільки мала позитивні перспективи розвитку. Зміни почалися в освітньому процесі - як для студентів, так і викладачів. Наукова й організаційна інноваційна діяльність продовжили розвиватися. Крім того, інноваційна діяльність була індивідуальною та колективною. Викладачі експериментували 3 навчальним планом, засновували нові кафедри, запроваджували цікаві й дієві методи викладання й елективні курси на четвертому році навчання, долучалися до розробки нових інструментів та апаратів, демонстрували успішні операції, відкривали нові хвороби, пропонували революційні методи лікування тощо. Студенти ставали відповідальнішими та відданими майбутній професії, отримуючи необхідні знання, уміння та навички відповідно до тогочасних викликів суспільства. Актуальним для майбутніх розвідок вважаємо висвітлення нормативноправової бази інноваційної діяльності медичних коледжів університетів США в історичному розрізі.

Ключові слова: американська медична освіта, Гарвардська медична школа, Массачусетський медичний коледж, інновації, дослідження, відкриття, Ч. Еліот, модернізація.
\end{abstract}

Introduction. K. Ludmerer notes that during Ch. Eliot's days, as president of Harvard University, from 1869 to 1909, Harvard Medical School underwent significant transformations from a private educational institution of the $19^{\text {th }}$ century to a modern medical school. At the beginning of Eliot's presidency, Harvard Medical School was no different from other private schools (Ludmerer, 1981). However, we disagree with the latter statement. Harvard Medical School was an innovative institution since its establishment.

H. Beecher and M. Altschule argue that "it is impossible to formulate criteria to define the quality of a medical school, but certain things seem important: innovation (italics is our $-A$. K.) and leadership, academic standings of the candidates for admission, the records of its graduates. By all these criteria Harvard has been an excellent school. Since 1782 Harvard Medical School has been associated with most of the world's great developments in medicine, often as either creator or challenger" (Beecher \& Altschule, 1977). Despite significant social, economic, and political challenges for the United States in the 1870s and 1900s, Harvard Medical School was a unique medical institution where faculty actively pursued innovations such as educational, organizational, and scientific ones.

Thus, the article aims to cover the development of innovative activities at Harvard Medical School during Ch. Eliot's presidency. Hence, there is the following task: to highlight chronologically important innovations of Harvard Medical School in the 1870s - 1900s and provide their brief description.

We have used the following research methods in the article: analysis, systematization, and generalization of scientific and pedagogical sources, and the method of historical and pedagogical reconstruction of events and facts that deal with the innovative activities of Harvard Medical School during the mentioned period.

Results. Note that in this study, we will use two names of the medical education institution - Harvard Medical School and Massachusetts Medical College. The fact is that from the beginning of its foundation until 1820, the institution had such a name as "Harvard Medical School". However, from 1820 to 1883, the institution was Massachusetts Medical College. In the sources of the 1820s - 1880s we often find the first name.

H. Beecher and M. Altschule pointed out that initially, Harvard Medical School was a private institution run by several well-known wealthy families, and department heads did their best to satisfy their interests or those of relatives or friends (Beecher \& Altschule, 1977). However, this did not prevent the teaching staff from carrying out the innovative activities to involve many students and recognition not only in the United States but also in the world.

When Charles Eliot became the President, there was a conceptual reorganization of the medical college. As a result, it united with the Harvard University. The thing was that from 1810 the connection of the medical college with the university was only formal. President Eliot pointed out that this institution was in a worse condition than other university departments, but with far-reaching prospects (Beecher and Altschule, 1977). Thus, from the 1870s, despite numerous discussions between President Eliot and the teaching staff, a new era of innovative development began for Massachusetts Medical College. Besides, President Eliot presided at every meeting of the Academic Council of the medical college (Clarence, 1906). President Eliot had the following two strategies: to improve 
the quality of the educational process and increase the credibility of the college. So, there was the agreement to admit only the best applicants to medical college through a strict admission procedure and to eliminate the principle of apprenticeship (Beecher \& Altschule, 1977).

In 1871, the educational process at Harvard Medical School underwent radical changes. The school year was extended by five months, for a total of nine months. Students were divided into groups. Each group studied from the first to the fourth year, took written exams at the end of the academic year to check the suitability of each student for transfer to another course. Moreover, H. Bowdich was the first full-time teacher in the history of American education. He also created the first physiological laboratory for students (Clarence, 1906; Beecher \& Altschule, 1977).

We would like to add that in the mentioned period the academic year consisted of two semesters with the important role of the didactic lecture. G. Shattuck, a professor at the Department of Theory and Practice of Medicine, thought that every student needed help on the path to independent practice. This philosophy inspired many Massachusetts Medical College students to achieve significant success during their years of the clinical study. Besides, the teaching of biological, toxicological, and clinical chemistry also became important (Clarence, 1906).

In $1872 \mathrm{~F}$. Knight opened the first clinic in New England, located in a small room in the amphitheater at the hospital. Doctors performed laryngoscopy in this clinic (Clarence, 1906).

In 1873, there were first attempts to eliminate general chemistry from the curriculum, as it was argued that a satisfactory grade in the general chemistry exam and qualitative analysis should be taken as the equivalent of an exam in these disciplines. Surgical histology was also taught for the first time. It was possible and effective due to the introduction of stained areas of tumors and pathological specimens (Clarence, 1906; Beecher \& Altschule, 1977).

Although the issue of women's health was not relevant in America, 1874 marked the emergence of a course in operative obstetrics with a practical demonstration on corpses (Clarence, 1906). It should be added that in the 1870s, Professor Biglow published work on methods to reduce hip dislocations and performed litholapaxy surgery, which positively affected the reputation of Massachusetts Medical College (Clarence, 1906).

In the 1870s and 1880s, T. Dwight created valuable collections of frozen variations of the human spinal cord, arms, and legs, a discovered intercuneoform bone. D. Cheever performed two successful consecutive ovariotomies and was the first to perform a cesarean section. He also believed that the hospital surgeon was responsible for helping patients and passing on experience to students and colleagues (Beecher \& Altschule, 1977).

In the 1880s, dissection rooms were equipped and the teaching program was improved. In this regard, University management appointed many teachers and assistants in anatomy (Clarence, 1906). Moreover, the teaching of surgery became systematic, as the course of lectures covered more surgical pathology, and the increase in clinical material allowed students to practice more (Clarence, 1906).

President Eliot, in his speech at Huntington Hall on the occasion of the centenary of Harvard Medical School in 1883, emphasized that "at the same time, the School has become a centre of chemical, histological, and sanitary research, as well as a place for thorough instruction; its students bring to School a better education than ever before, they work longer and harder while in the School, and leave it prepared, so far as sound training can prepare them, to enter, not the overcrowded lower ranks of the profession, but the higher, where there is always room" (Exercises in Huntington, 1883).

Doctor of Medicine, Dean of Massachusetts Medical College in 1850, O. Holmes said in his speech: "The Medical School of Harvard University enters, with the commencement of the present season, upon the second century of its existence. By a fortunate coincidence, it takes possession at this same time of the noble edifice which a generous public has reared for the use of the teachers and students of this institution" (Holmes, 1883).

In 1883, Harvard Medical School moved to a new building on Boylston Street, and the word "gynecology" appeared in the curriculum. From 1888 histology began to develop rapidly (Clarence, 1906).

In the early 1890s, the teaching staff of Harvard Medical School began to replace the old model of student attendance with so-called "clinical exercises". The feature of such exercises was that the student had to meet with the patient and get a history, conduct an examination, or use any other manipulation that would allow him to obtain more information about the patient. Note that all this was done under the strict supervision of teachers (Clarence, 1906).

To obtain a degree, in 1895-1902 a student had to pass exams, take part in a clinical conference and write short reports on four outpatient cases. Observing patients at home allowed students to become acquainted with private medical practice (Clarence, 1906).

Besides, at that time there was a revision of the teaching at the Department of Chemistry. Thus, the teaching of medical chemistry became almost entirely medical and in its broadest sense. In 1898 the course in pharmaceutical and physiological chemistry was established (Clarence, 1906).

Note that after studying each clinical discipline, students had to take part in departmental conferences, where they made reports describing interesting examples. Successful material could be published in local scientific journals (Clarence, 1906).

From 1897 to 1898, hygiene was a compulsory study for the first time in the history of Harvard Medical School. This discipline was taught by Ch. Harrington in the fourth year in the second semester (Clarence, 1906).

At the end of the $19^{\text {th }}$ century, Professor Porter proposed a system of teaching that differed in concentration and consistency. According to this system, during the first semester of the first academic year, the student devoted 
all his time to anatomy and histology, and during the second semester - to physiology and physiological chemistry. This teaching system had three advantages:

- students studied the structure in detail before considering the function;

- students had only one teacher;

- teachers successfully corrected experimentation and didactic teaching (Clarence, 1906).

So, in 1899, Professor Potter became responsible for teaching the first-year students, implementing a new teaching method, and providing students with devices suitable for laboratory experiments of physiology (Clarence, 1906).

Professor White was a core figure for Harvard Medical School. He became a pioneer in dermatology, transformed the curriculum, strengthened the speciality, and promoted dermatological education than anyone else in the United States (Clarence, 1906).

1899 marked the establishment of the Department of Bacteriology, where the focus was on research, especially on the study of tuberculosis, rabies, smallpox, diphtheria, typhoid fever, fever, etc. Among successful projects of the department, there were the use of ultraviolet photomicrography and the improvement of rapid diagnosis of rabies (Clarence, 1906).

Note that F. Hooper made and modified several instruments that used in laryngological practice. Besides, for the first time, he performed surgery to remove adenoids under general anesthesia (Clarence, 1906).

In the 1900s, the recitation of textbooks was replaced by sectional teaching. Firstly, during the second year, students studied the symptoms of a disease and ways to collect medical history. After that, attention was focused on the importance of laboratory tests, their interpretation. Subsequently, students received case histories for study, involving all laboratory research methods to learn as much as possible about the case. Such teaching continued within the first half of the third year with more complex case histories and detailed analysis and evaluation by teachers regarding the application of acquired knowledge, skills, and abilities by individual students. Moreover, students visited patients and had to observe changes in their general physical condition and laboratory tests of blood, urine, feces, stomach contents, etc. (Clarence, 1906).

V. Servant-Miklos notes that in the early $20^{\text {th }}$ century Harvard Medical School, introduced a case-based program, namely the case method. However, the pedagogical specificity of the case method at Harvard Medical School reduced the role of the teacher as a direct transmitter of knowledge and required students to learn on their own previous material on which teachers conducted surveys. The case method was replaced by problem-based learning (Servant-Miklos, 2019).

We would like to add that during the fourth year of study, students were more attracted to elective courses, including pathological anatomy, operative surgery, obstetrics, dermatology, ophthalmology, etc. because they had clear plans with a lot of practice. For example, after completing a course in obstetrics, students had the opportunity to continue studying obstetrics in three developed areas. In the course in pathological anatomy, students were initially present at postmortem examinations in hospitals to study the signs and symptoms of illness during life and the cause of death. Then students examined samples of fluids, blood, etc. to identify present lesions that would clarify the prognosis and treatment of similar future cases (Clarence, 1906).

Also, note that in the early $20^{\text {th }}$ century the teaching of pediatrics at Harvard Medical School was thorough and provided students with more opportunities than at any other medical school in the United States (Clarence, 1906).

In 1902, there were changes in the curriculum, according to which the first three years were devoted to compulsory subjects, and the fourth to elective courses, with a minimum of one thousand hours of work. A new curriculum with elective courses was introduced in the fall of 1905. The degree of doctor of medicine with honors was awarded to students who received an average of eighty percent or more in all required examinations (Clarence, 1906).

Beginning from 1902, each student was required to study interesting cases, case histories, physical examinations, and chemical and microscopic examinations for one month under the guidance of any Harvard Medical School teacher at the hospital. In 1903, elementary organic chemistry was added to the admission (Clarence, 1906).

In the fall of 1903, a new outpatient ward for skin diseases was opened at the Massachusetts General Hospital with 16 beds. For students, it was a unique opportunity to see many examples of skin diseases, especially bedridden and bullous patients (Clarence, 1906).

Moreover, in 1905 the Department of Theory and Practice of Medicine developed a textbook on the basics of medical diagnostics. Other clinical departments took this work as a basis for teaching, which eventually led to the unification of the educational process of Harvard Medical School (Clarence, 1906).

Harvard Social Service at Massachusetts General Hospital was also an interesting example of innovations. In 1905, R. Cabot offered a plan with a list of questions that one needed to know when providing social service to patients. In particular, attention was focused on issues such as caring for patients with tuberculosis, feeding and caring for newborns, psychological support for those in need, etc. (Beecher, Altschule, 1977).

The innovative activity of Harvard Medical School also includes the fact that faculty have invented many new tools and modified others to ensure ease of use. However, the manufacture of such tools was redundant. The management of the Harvard University decided to sell other universities those instruments at prices much lower than the real cost. In 1906, more than one hundred and sixty American laboratories and about fifty foreign laboratories, including in Syria, Russia, Japan, Australia received the Harvard Physiological Apparatus (for artificial lung ventilation) (Clarence, 1906, Beecher \& Altschule, 1977). A detailed description of the physiological apparatus 
can be found in the article "Physiological Apparatus in Use at the Harvard Medical School" (1879) by H. Bowditch (Bowditch, 1879).

Conclusions. It should be noted that when Charles Eliot became the President of Harvard University in the early 1870s Harvard Medical School attracted considerable attention because it had positive prospects for development. Changes began in the educational process - both for students and academic staff. Scientific and organizational innovation activities continued to develop. Besides, note that innovation was individual and collective. Professors experimented with the curriculum, established new departments, introduced interesting and effective teaching methods and elective courses within the fourth year of study, participated in the development of new tools and devices, demonstrated successful operations, discovered new diseases, proposed revolutionary treatments, etc. Students became more responsible and devoted to their future profession, gaining the necessary competencies within the challenges of society at that time. As for future research, we consider covering the regulatory framework for the innovative activities of medical colleges in U.S. universities within historical terms.

Bibliography:

1. Beecher H.K., Altschule M.D. Medicine at Harvard: The first three hundred years. Hanover, N.H. : University Press of New England, 1977. $587 \mathrm{p}$.

2. Bowditch H.P. Physiological Apparatus in use at the Harvard Medical School. The Journal of Physiology. 1879. Vol. 2, Issue 3. P. 202-205. DOI: https://doi.org/10.1113/jphysiol.1879.sp000057.

3. Clarence E.H. The Harvard Medical School: 1782-1906. Boston, 1906. 212 p.

4. Exercises in Huntington hall, Massachusetts institute of technology. Addresses and Exercises at the one hundred anniversary of the foundation of the medical school of Harvard University, October 17, 1883. Cambridge : John Wilson \& Son, University Press, 1884.55 p.

5. Holmes O.W. The address delivered in Huntington Hall. Addresses and Exercises at the one hundred anniversary of the foundation of the medical school of Harvard University, October 17, 1883. Cambridge : John Wilson \& Son, University Press, 1884. $55 \mathrm{p}$.

6. Ludmerer K. Reform at Harvard Medical School, 1869-1909. Bulletin of the History of Medicine. 1981. Vol. 55. № 3. P. 343-370. URL: http://www.jstor.org/stable/44441382.

7. Servant-Miklos V.F.C. The Harvard Connection: How the Case Method Spawned Problem-Based Learning at McMaster University. Health Professions Education. 2019. Vol. 5, Issue 3, P. 163-171, URL: https://www.sciencedirect.com/science/ article/pii/S2452301118300956.

References:

1. Beecher, H.K., Altschule, M.D. (1977). Medicine at Harvard: The First Three Hundred Years. Hanover, N.H.: University Press of New England.

2. Bowditch, H.P. (1879). Physiological Apparatus in use at the Harvard Medical School. The Journal of Physiology, 2 (3), 202-205. DOI: https://doi.org/10.1113/jphysiol.1879.sp000057.

3. Clarence, E.H. (1906). The Harvard Medical School: 1782-1906. Boston.

4. Exercises in Huntington hall, Massachusetts institute of technology. In Addresses and Exercises at the one hundred anniversary of the foundation of the medical school of Harvard University, October 17, 1883 (pp. 36-49). Cambridge John Wilson \& Son, University Press.

5. Holmes, O.W. (1883). The address delivered in Huntington Hall. In Addresses and Exercises at the one hundred anniversary of the foundation of the medical school of Harvard University, October 17, 1883 (pp. 3-35). Cambridge John Wilson \& Son, University Press.

6. Ludmerer, K. (1981). Reform at Harvard Medical School, 1869-1909. Bulletin of the History of Medicine, 55 (3), 343-370. URL: http://www.jstor.org/stable/44441382.

7. Servant-Miklos, V.F.C. (2019). The Harvard Connection: How the Case Method Spawned Problem-Based Learning at McMaster University. Health Professions Education, 5 (3), 163-171, URL: https://www.sciencedirect.com/science/article/ pii/S2452301118300956. https://doi.org/10.1016/j.hpe.2018.07.004. 